\title{
An Analysis of Speech Acts Used by the Seventh-Grade Teacher of SMPN 2 Bangli in EFL Classroom Interaction
}

\section{Ivana Swastiana N.M1 ${ }^{*}$, Adi. J. Putra I.N², Suarnajaya I.W3}

1,23 English Language Education, Post Graduate Program, Universitas Pendidikan Ganesha, Singaraja

\begin{tabular}{l} 
A R T I C L E I N F 0 \\
\hline Article history: \\
Received 29 December \\
2019 \\
Received in revised \\
Form 01 January 2020 \\
Accepted 18 January \\
2020 \\
Available online 28 \\
February 2020 \\
\end{tabular}

Keywords:

Speech Acts, English as a Foreign Language (EFL), Classroom Interaction

\begin{abstract}
A B S T R A C T
Speech act is an action performed via utterances. This study investigated the types and functions of speech acts used by the seventh-grade English teacher at SMPN 2 Bangli by adopting Searle's theory. The data were obtained through classroom observation and semi-structured interview. The data were analysed qualitatively by using Miles and Huberman's interactive model. It was found out that there were five types of speech acts used by the teacher, namely representative, directive, expressive, commissive, and declaration in which directive $(47.52 \%)$ was dominantly used by the teacher, while the declaration was the one which was less produced $(0.71 \%)$. Among the functions of directive act, commanding appeared the most (44.40\%), while naming and declaring were in the same amount in declaration type $(50 \%)$. The teacher's directive acts proved that she played her role to manage the classroom instructional system, to counsel the students and their learning, to instruct and to assess. However, the teacher, who also acted as the homeroom teacher and was in authority during the English lesson, performed the declaration act to change some situations in the classroom.
\end{abstract}




\section{Introduction}

Language is human communication system which comprises the structured arrangement of sounds (or their written representation) into larger units, e.g. morphemes, words, sentences, utterances (Richard and Schmidt, 2002). Intentional interaction during teaching learning process in the classroom occurs between teacher and students by using language. Through their speech, teacher and students establish communication properly to achieve better learning outcomes. Pragmatics is a linguistics branch which is associated with meaning in context. it is important both for the speaker and listener to have pragmatic language skills to develop relationship and communication ability in various contexts. Their linguistic knowledge, the utterance context, knowledge about the status of those involved, and the speaker's inferred intention are several issues which determine how the meaning of utterances is successfully transmitted. In pragmatics area, the language function is studied in speech acts (McCarthy, 1991). If we refer to other concept of speech acts, every utterance basically holds three elements: locution, illocution, and perlocution. Locution is what the speaker says, illocution is the purpose of what speaker says, and perlocution is the effect of what the speaker says (Cutting, 2002 in Widya, 2017). From those three acts, Yule (1996: 49) states that the illocutions are the most often discussed acts in pragmatics. The whole utterances which are used as a medium in classroom communication belong to classroom speech act.

Classroom speech act is such an important issue for teachers as it can provide information on what kind of teaching behaviours they perform extensively in communicating with their students. Hence, it shows the quality of verbal interaction in the classroom (Merdana, Seken, Putra, 2013). In line with this idea, Consolo (2006) also claims that students' language development is greatly influenced by the use of various language functions in the classroom in the interaction between teachers and students. However, in EFL classroom setting, such as in Indonesia, teachers and students should pay attention to several things, such as idiomatic expressions and cultural norms (Hidayat, 2016). These factors could be troublesome to the hearers if they do not really understand the utterance meaning. It is due to the fact that their assumption on their first language rules and conventions are also applicable to the foreign language. It can also be caused by their ignorance toward the idiomatic expressions and cultural norms in foreign language. For example, the research conducted by Karimnia and Afghari (2011) who highlighted different ways in complimenting between Americans and Persians which proved that culture contributes to different style of language use.

Besides cultural matter, teacher's language is one of other important factors which determine the success of English teaching and learning process. In EFL classroom setting, the English teacher, which is a non-native speaker of English, experiences problems in delivering the lesson using English and making the students understand the instructions in English. Nuraini (2015) finds that Indonesian students get misunderstanding toward the the teacher's use of speech acts in the classroom for uttering speech acts inappropriately. Various interpretations may come into students' mind only from a simple utterance spoken by the teacher. It is caused by the teacher's failure on using IFIDs (Illocutionary Force Indicating Devices) or determining to use either direct or indirect speech act in particular situation. For an instance, when the teacher chooses to be more indirect to the students, her utterance such as "How dirty the classroom is!" can be interpreted in two ways. Firstly, dealing with locutionary act, it can be understood as the teacher who is simply expressing her dismay about the physical situation of the classroom. Secondly, in terms of illocutionary act and its force, the utterance can be categorized as directive act with the function of commanding. When the teacher produces the utterance, she tries to ask the students to clean the classroom as soon as possible before the lesson starts.

Another reason for conducting this research is characteristics differences among different generations. In educational field, there has been found a lot of teachers who are dissatisfied with their students' behaviours which are different from that of their own childhoods (Sriprom, et.al, 2019). The gap occurs between them causes misunderstandings, misperceptions and lack of compassion. It is due to the fact that each generation shares their own "peer personality" and it leads to collective thought. It means someone may think that the generation from where he/she was born will be similar with other generations. In fact, a report conducted by Nielson Holdings Plc. (2018) in Sriprom, et.al (2019) finds that different generations bring out their own unique behaviours which present unique challenges for others. It makes teachers need to be aware of these generational differences to help them find and integrate the most appropriate pedagogical techniques for students of Gen Z (Ferrari, 2018 in Sriprom, et.al, 2019). In their era, information technology has developed rapidly. However, to anticipate the absence of technology in the classroom, teacher should focus on activity and interaction, rather than memorization and rules (Miriam, 2011 in Harmanto, 2013). It is suggested for teachers to use Total Physical Response method which allows students to learn by doing or real communication instead of repetitive reading or writing. Thus, it is clear that teachers should understand that the characteristics of gen $\mathrm{Z}$ are truly different from 
the previous generations. Their belief and knowledge about what is important to teach, how students learn, how to manage students' behaviour and meet external demands are such significant matters to consider before entering classroom.

Apart from the phenomena encountered in the classroom above, research on teacher's speech acts especially in EFL context has not been done adequately. Most previous researches focus on the speech acts used in political speeches, movies, novels and short stories. In order to break the research scarcity, thus, this research was conducted. This research was conducted to investigate the speech acts implemented in EFL classroom conversation, including the types of speech acts used by one of the English teachers in her classrooms as well as their functions.

\section{Methods}

Analysed by using John R. Searle's speech act theory, this study adheres to the principle of qualitative research design. The participant involved in this study was the English teacher of the seventh grade at SMPN 2 Bangli who taught six classes - VIIA, VIIB, VIIC, VIID, VIIE, and VIIF. She participated in this study during the teaching and learning process in the second semester in 2018/2019 academic year. The data were gathered through classroom observation and a semi-structured interview. All classroom observations were recorded using a handy-cam to aid the researcher in collecting the data. The collected approximately 480-minute tapes from the six classes were transcribed verbatim, making them the main data source. Besides, the researcher also used the data sheet which was used to assist the researcher in identifying and analysing the data. After doing the classroom observation, the researcher conducted a face-to-face interview with the seventh grade English teacher at SMPN 2 Bangli. A mobile phone was used by the researcher as an instrument to record the interview data from the teacher as the interviewee. In the meantime, the researcher also did note-taking to obtain additional information during the interview. In this study, the interview method was conducted to get more detailed information regarding the functions of the teacher's use speech acts in her classes. It aimed to understand the reasons of using the speech acts in the classrooms and thus to explore more deeply the teaching considerations of these acts. The interview result was also used to triangulate the data obtained through classroom observation. It means the researcher asked questions to the teacher to ensure the functions of the speech acts uttered by the teacher was exactly the same as those understood by the researcher during the observation. Miles and Huberman's interactive model (1994) of data analysis was used to analyse the data. It consists of three cyclical steps, namely data reduction, data display and conclusion drawing/verification. Data reduction associates with the process of selecting, focusing, simplifying, reducing, and organizing the data which has been collected. In this step, through a careful reading of the transcribed conversations, the selected data which were related to the objectives of the study were identified and organized into a profile in which all of its relevant characteristics were specified while the irrelevant data were eliminated. The next step after reducing data is data display. It is concerned with presenting an organized, compressed, assembly of information for conclusion drawing. It can be in the form of texts, graphs, diagrams, charts, or other graphical formats. This data presentation for this research was arranged in the form of table which later was explained descriptively in the form of essay. Drawing some inferences are the final step after data presentation. This phase allows the researcher to move back to consider the analysed data mean and to assess whether the data findings fit the objectives of the study. At this phase, the data which had been analysed were read and re-read to develop the conclusions regarding the study. The conclusions, later, were verified continuously. It meant revisiting the data as many times as necessary. The researcher also applied peer checking and consultation with the supervisors to enhance the verification. Methodological triangulation was meant as using one or more methods to collect the data. This research employed two methods to validate the data findings, namely classroom observation and interview. After the researcher got the data collected through the observation during the teaching and learning process in the classroom, she crosschecked the data by conducting interview with the seventh grade English teacher. In addition, the researcher also employed investigator triangulation. Here, the researcher crosschecked the data obtained from the classroom observation to two experts. At first, the researcher identified and classified the types and functions of the seventh grade English teacher's speech acts based on her view. Then, she consulted it to two experts of pragmatics study.

\section{Result And Discussion}

There are five types of Searle's speech acts performed by the English teacher of grade VII SMP Negeri 2 Bangli during the teaching and learning process. They were representatives, directives, expressives, commissives, and declaratives. The table shows that the most dominant speech act used by 
the teacher was directives with 268 examples which represent $47.52 \%$ out of the total number of utterances.

Representative speech act took the second place among the other types. It existed in 180 utterances reflecting 31.91\% out of the total utterances. The 69 utterances of expressive speech act posited the third place with $12.23 \%$ out of the whole speech acts. It, then, was followed by commissive speech acts in the fourth place with 43 utterances which equals $7.62 \%$ out of the total utterances. Meanwhile, declaration speech act was the least speech acts employed by the teacher during the teaching and learning process. It was revealed in 4 utterances with $0.71 \%$ out of total utterances.

Dealing with the functions of the teacher's representative speech acts, the table shows that the teacher produced confirming, correcting, agreeing, disagreeing, explaining, informing, stating, predicting, describing, and identifying. According to the level of occurrence, the most frequently used representative speech act was confirming with 47 utterances (26.11\%). The second place was informing with 45 instances (25\%). The third position was occupied by describing with 25 utterances (13.89\%). The next position of representative function was stating with 16 utterances (8.89\%). It then was followed by 15 utterances of correcting (8.33\%) and 14 utterances of explaining (7.78\%). Agreeing was in the next place with 8 utterances (4.44\%), directly followed by disagreeing with 7 utterances (3.89\%). Identifying which occurred in 2 utterances $(1.11 \%)$ made it the second least rank. Meanwhile, the least frequently used function of representative speech act was predicting which appeared in 1 utterance $(0.56 \%)$.

The teacher also performed various functions of directives speech acts. They are asking, commanding, requesting, suggesting, directing, reminding, warning, prohibiting, and persuading. Commanding, which appeared in 119 utterances (44.40\%), was the most frequently directives speech act used by the teacher. Asking was expressed in 109 utterances with $40.67 \%$ out of the whole data making it occupy the second place. Reminding was in the next rank with 14 utterances (5.22\%). The fourth rank went to directing with 11 utterances or $4.10 \%$. Requesting was realized in 7 utterances $(2.61 \%)$. The second least rank was suggesting with 5 utterances with the percentage $1.87 \%$ out of the total. Warning prohibiting, and persuading were the least frequently used directive functions with 1 utterance $(0.37 \%)$.

Concerning the function of expressive speech acts, the table shows that the teacher performed greeting, thanking, praising, apologizing, wishing, stating surprise, stating pleasure, stating annoyance, stating dislike, stating anger, and leave taking. The most frequently used expressive speech acts function was revealed in the form of thanking which occurred in 21 utterances $(30.43 \%)$. The second place was occupied by praising with 19 instances (27.54\%). Stating surprise was in the third rank with 9 utterances (13.04\%). Greeting and leave taking posited the next ranks with 6 and 5 utterances respectively (8.69\% and $7.25 \%$ ) respectively. There were 2 utterances utilized by the teacher for each function of wishing and stating annoyance with the percentage $2.90 \%$ out of the total occurrence. Meanwhile, the least frequently used functions of expressive speech act were apologizing, stating pleasure, sorrow, anger and like. They were found only in 1 utterance $(1.45 \%)$.

In terms of commissive speech acts, the teacher produced three functions, namely promising, offering and granting. The most frequently used was offering with 18 utterances (41.86\%), while the least went to promising which was expressed in 8 instances (18.60\%). Another function of commissive performed by the teacher was granting. It was realized in 17 utterances $(39.53 \%)$.

Declaration was the least frequently type of speech acts produced by the teacher. There were only 2 functions utilized by the teacher, namely naming and declaring which appeared in the same amount of utterance. Both of them were found only in 2 utterances with the percentage of $50 \%$ out of the total data occurrence.

\section{a. Representatives}

Confirming

Confirming is done in order to establish the truth or correctness of something which is previously believed to be the case. This function of speech act occurred in 47 utterances. Here is an example of confirming act:

(1)

$\mathrm{T} \quad$ : Ok, Ibu sudah beri kalian PR, Rama kayaknya di WA nanya PR ya? (Ok, I have given you

homework, was it Rama who asked question about homework in WA?)

S : Ya, bu. (Yes, Ma'am)

T : Bu, diganti namanya, apa maksudnya ini. (Ma'am, (we are supposed to) change the names, what does it mean?) 
In (1), the teacher intended to discuss the homework along with the students. At first, she wanted to make sure whether the student who proposed her a question related to the homework she had given via WhatsApp on the previous day. The message she received proved that the teacher abode by quality maxim. She did the confirmation based on the evidence she owned - a message she received from the student. After the student confirmed it by saying "Yes, Ma'am", she then confirmed the question that the student asked her. In this case, the students had to make an indirect speech from a direct speech spoken by some speakers. The question was about if the student had to change the names of the speakers in the indirect speech. The student's response toward the teacher's confirmation which signed that it was him who sent the message showed that the teacher also abode by the quantity, relevance, and manner maxim. The student could understand well the teacher's confirming act and did not deny the teacher's statement. The form of the utterance above was interrogative and it had implicit confirmation form since there was no any performative verbs indicating confirmation used in this utterance. The teacher chose to use interrogative form which made it indirect confirming speech act.

\section{Informing}

Informing has a goal to tell someone about certain facts they do not know. There were 45 utterances (25\%) of informing act in this study. One of them is presented as below:

T: Small, handsome. Do you know handsome? (The students were silent) Ganteng.

Describing people is the context of the utterance in (2). The teacher was describing a male student who stood in front of the class by using adjectives. She asked the students the meaning of handsome. Unfortunately, the students did not respond to the teacher's question since they did not know the answer. Thus, the teacher told them the correct meaning. In this case, the teacher stated what she believed in and the direction of fit was words to world. Consequently, it made this utterance belongs to representatives. This fact also made the teacher had fulfilled the quality and relevance maxim. Her short answer to inform the meaning of the word in Indonesian language which was stated clearly meant that she had conformed to the quantity and manner maxims. This utterance was classified as direct and implicit speech act for its declarative form and absence of performative verb "inform".

\section{b. Directives}

Commanding

Commanding has a purpose to ask for something to be done. An expression of commanding can be seen in the example below:

(3)

\section{T: Ok, dialog berikutnya (Ok, the next dialogue). Ayudiah, please Ayudiah, come on.}

The learning topic in (3) is describing something. After getting the students understand the concept of the use of the expression "What is he/she like?", the teacher asked some pairs of students to come forward and read dialogue. She had appointed three pairs of students beforehand based on the amount of the dialogues. After the first two pairs had finished reading the dialogue, the teacher commanded the student named Ayudiah to read her part. Here, the quality, quantity, relevance and manner maxims were fulfilled when the teacher called a name of one of her students to read the next dialogue clearly so that the student came forward and did the teacher's command. In her utterance, the teacher used imperative form in commanding the student. She used direct speech acts since she had higher position than the students. Nevertheless, she employed the word "please" to soften the demand. It also belonged to implicit commanding speech act since the teacher did not mention any performative verbs in her command.

\section{Asking}

Asking is used to get an answer from the hearer by raising a question. It also functions as elicitation. With the teacher's questions, the students are expected to participate actively during their learning process. Furthermore, they feel motivated to activate their background knowledge of the topic being discussed. Therefore, it enables the teacher to identify the students' comprehension level. The following is an example of asking: 
(4)

T: Do you understand what did you write just now? Sudah paham yang kalian tulis? (Have you understood what you wrote?) Maksudnya. (The meaning)

Ss: Belum. (Not yet)

In (4), the teacher asked the students of class VIID whether the students had already understood the meaning of "What is she like?" as an expression that the students had to copy from their textbook. The teacher met the quality, relevance and manner maxims for she asked the students something that the students had already done before - copying the sentences from the textbook and the students responded her question. She also met the quantity maxim for asking the students both in English and Indonesian to make sure that the students comprehended what she asked. The teacher performed directives because she wanted the students to do something for her, that was answering her question. Besides, it was marked by the use of interrogative form, especially Yes or No question by using the word "do". However, she did not use any performative verb in her command. These facts meant that the teacher used direct and implicit commanding speech act.

There are some conditions that the utterance meet as a questioning act. Firstly, the teacher has fulfilled the content condition. She believed that the students would answer her question. Secondly, the preparatory condition specifies that the teacher did not know if the students understood the meaning of the expression the students had written. Thirdly, the sincerity condition was fulfilled when the teacher genuinely wanted to get the information from the students. Lastly, since the teacher's utterance regarded as an effort to elicit an information from the students, she had met the essential rule.

\section{c. Expressives}

There is a type of speech act which expresses the speaker's feelings or psychological states namely expressives.

Thanking

Thanking is expressed to someone that we are grateful for something that they have done. An illustration of thanking is presented below:

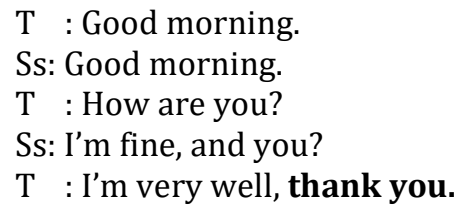

The utterance in the bold-typed in (5) above belongs to expressive since it expresses the speaker's feeling or emotions toward the proposition. This gratitude expression was performed by the teacher because the students of class VIIA asked how she was after the teacher did the same way in the opening activity. It meant the quality and relevance maxims were adhered by the teacher. Here, the "thank you" expression delivered by the teacher directly and clearly is classified as direct and implicit thanking speech act.

\section{Praising}

The function of praising is to express admiration or approval toward someone's achievement or something's characterictics. An instance of praising is stated below:

(6)

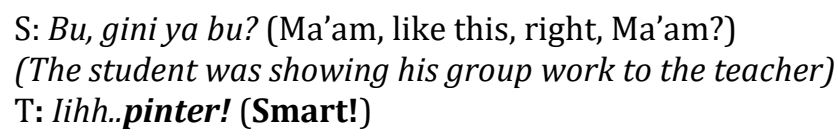

In (6), it shows how the teacher praised the student for doing the task correctly. She used the word "smart" to express her praise to the student. In this case, the quantity and manner maxims were met for the utterance had been able to represent what the teacher felt. She said so after the student showed his group work to ensure whether he had done right. After checking it for a while, the teacher expressed her 
praise while pinching the student's cheek to show her pleasant feeling. It meant she delivered the utterance by considering the quality and relevance maxims. The teacher's utterance is included into direct and implicit praising act which is used to express the psychological state of the speaker with no performative verb. Here, the teacher had put an attempt to make her words fit the world of her feeling.

\section{d. Commissives \\ Offering}

Offering is produced to ask someone if he/she would like to do or to have something. One of the teacher's offering acts is exemplified below.

T : Sukra, mau nggak kesana, Sukra? Ke Yogi. Yogi memberikan influence jadinya. Tapi, Ibu maunya gini, Sukra dan Yogi berdempetan. (Sukra, do you want to sit there or not, Sukra? To Yogi. Yogi gives influence. But, I actually want Sukra and Yogi sit side by side.)

(Then, Sukra moved to sit besides Yogi)

In (7), the teacher produced the utterance in the middle of seating arrangement. She commanded some students to move in such a way in order to enhance the learning process and atmosphere in the classroom. The teacher mentioned one student's name, Sukra and offered him whether he would like to move to sit near Yogi. She made an offer by saying "Sukra, do you want to sit there or not, Sukra?" She produced the act by using interrogative form which made it direct yet implicit for no imperative verb was used in the utterance. Her utterance was successfully performed and her intended message was received by the student which signed the quantity and manner maxims were fulfilled. Although the student did not say anything, he could accept the teacher's offer by standing up as a sign to get ready to move near Yogi, the student whom she appointed Sukra to sit near with. Then, she let Sukra to sit beside Yogi. In performing the act of offering, the teacher employed preparatory condition in which she was uncertain if the student wanted to move to another seat. As a result, she offered him by asking him. Here, the quality and relevance maxims were also fulfilled by the teacher.

\section{Granting}

Granting is intended to give or allow someone something. It usually deals with accepting requests. The table below illustrates an act of granting:

(8)

$\mathrm{T}$ : Baik, sekarang lihat dibawahnya, coba sekarang praktekkan dibawahnya, di halaman seratus dua puluh empat, dua puluh lima. (Ok, now look at below it, try to practice below it, on page one hundred twenty-four, twenty-five) Fill the blanks. Anak-anak boleh berdiskusi dengan temannya. (You may discuss with your friends.)

$\mathrm{S}$ : Bertiga boleh ya bu? (May we make it in three, Ma'am?)

$\mathrm{T}$ : Iya, bertiga, yang berdua ya berdua, biar nggak ribut. (Yes, in three, who sits in two, in two, so that it won't be noisy)

In (8), the teacher asked the students to do the task on page 124 and 125. Here, the teacher allowed the students to discuss it in groups. One student asked the teacher whether he could make a group of three. The teacher let the student to do so by saying "Yes, in three". This short and clear granting act given after the student's question indicated the teacher abode by the maxims of quality, quantity, relevance and manner. This utterance is classified as direct and implicit commissive speech act with the function of granting without performative verb. It belonged to commissive since it showed one's commitment to do some future actions. In this case, the teacher's commitment was letting the student to create a group which consisted of three students.

\section{e. Declaration}

Naming

Naming has a purpose to officially choose someone or something, especially for an important job or prize. An example of naming is shown in the table below: 
(9)

S: Bu, nggak boleh ya saya didepannya Suartana? (Ma'am, can't I sit in front of Suartana?)

T: Nggak. (No) Suartana kalau disana dia ngorte. (If Suartana is there, he keeps talking) Ini Suartana biar ada Agusnya. (Suartana is here to be with Agus) Agus kalau disana jadi senternya dia. (If Agus is there, he becomes the center) Disana ada Sukra, ada Sandiasa, 'kan jarang ngomong dia. (There are Sukra and Sandiasa there so they will rarely talk)

In (9), in the middle of seat arrangement setting in the classroom, one student asked the teacher if he could sit in front of another student named Suartana. Previously, he had been already seated beside Suartana, one of some students with unpleasant behaviour. Meanwhile, the student belonged to one of excellent students in class VIIA. Thus, the teacher did not grant his wish and explained her reason why. She, further, named him the center among the students with unpleasant behaviour. He was named so and placed him among them because the teacher thought he was such a reliable student to help his friends in improving their learning and attitude. The bold-typed utterance is classified as declarations with naming act since it is performed by the speaker to change the world. By saying the utterance after arranging the seat, the teacher named Agus the centre which changed Agus become the student which was expected to help his misbehaved friends to be better students. In this case, the teacher, who was the homeroom teacher of class VIIA as well, had an authority to arrange the seat in such a way for better learning outcomes and atmosphere. Thus, it made the quality, quantity, relevance and manner maxims were fulfilled.

Declaring

The aim of declaring is to state officially and publicly that a particular situation exists or that something is true. Here is an instance of declaring act performed by the teacher in the classroom:

\section{T: Sudah selesai beberapa teman kalian (Some of your friends had finished) Sudah bisa (They had been able to do it). Pemakaiannya sudah benar, tinggal praktek (The use had been correct, and next would be the practice)}

The expression in the bold form in (10) above indicates that the teacher performed an act of declaring. In this case, the teacher declared that some students of class VIID had been able to create the dialogue. Previously, she asked the students to create a dialogue in pairs by using expression "what is it/she/he like?". In the middle of students' discussion, there were some students came to the teacher's desk and consulted their work to the teacher. After doing some checking, the teacher found out that they had been able to make it. Thus, she declared to the class that some of them had been able to create the dialogue as she wished. By saying the utterance, she produced the declarations speech acts. She meant that the students who previously found difficulties in understanding the meaning of the expression, eventually successfully had understood the expression which could be seen in the dialogue they had created. Here, the teacher held the authority to perform the declaring act since she acted as the English teacher who taught the class from the beginning until the end of the lesson. She, then, knew well that there had been a progress of her students' learning during the class on that day. These facts brought to a notion that the four conversational maxims were fulfilled. The declaration form of the utterance without any performative verbs caused the utterance was classified as direct and implicit declaring speech act.

Among the five types of speech acts used by the seventh grade EFL teacher in her classrooms, directive was the most dominant speech act performed by the teacher since during the six meetings in English teaching and learning activities. Moreover, among the nine functions of directive speech act used by the teacher, commanding was found to be the most performed speech act. In the classrooms, the teacher often commanded the students to do something, such as paying attention to her, submitting their homework, reading dialogues, working in groups, doing the task and obeying the school rule. Besides, the teacher's use of asking allowed the students to think more critically on a particular problem. She did not give the answer directly, rather asking students to think about the answer. It belonged to one of eight classroom functions used by teacher, namely eliciting as proposed by Spatt, Pulverness, and Williams (2009). Besides eliciting, another classroom function used by the teacher was prompting in which the teacher helped the learners think of ideas or to remember word by giving them part of it (Spatt, Pulverness, and Williams (2009)). It was similar with the teacher's function of directing in which the teacher provided a word or other clues to help the students describe their family member's job and understand the difficult words. In addition, the teacher was also aware on the benefits for the students if 
they did good things. Thus, she performed reminding and suggesting functions to the students, such as doing their homework, keeping the classroom clean, reading and exercising a lot, and creating good relationship with their friends. The teacher also used it to draw conclusion along with the students at the end of the lesson to check their knowledge and comprehension. It made these facts were in line with the notion of directives speech acts which requires the hearers to undertake some actions for the speaker and to guide their behaviour (Krish and Ervin Tripp as cited in Merdana, et.al (2013)). Besides, the teacher also played her roles in EFL classrooms, such as becoming the manager of classroom instructional system, the counselor of students and consultant of learning, instructor and assessor (Johnson, et.al, 1998). In regard with classroom speech acts, Searle (1969) also maintained that directive is a kind of speech act which is mostly used in classroom interaction. Differently, in this study, declaration was the least frequently used type of speech act by the teacher in teaching English in the classroom. It was because in performing a declaration act, a special institutional role attached to the speaker was required. At the beginning of every academic year, some teachers were appointed as homeroom teacher as well classes who were in their teaching responsibility. However, in relation to the principle of declaration which was used to change the situation around the utterance, there were not many of teacher's utterances were used to do so. Only in few occasions, the seventh grade English teacher who also acted as the homeroom teacher and was in authority during the English lesson performed two functions of declaration speech act, namely naming and declaring. She managed to perform these functions since she was the homeroom teacher of one of the seventh grade classes who had an authority to do the seat arrangement and put the most brilliant student in the middle of their friends to help them in their learning. Besides, during her English class, she made the students acted out the dialogue based on the name of the speakers she mentioned, declared that the students had successfully mastered a particular topic and that the English lesson was over. The asymmetrical relationship between the teacher and students in terms of age and status made the teacher exerted her power over the students through these declaration acts

\section{Conclussion}

Regarding the objective of the study, which is to find out the types of speech acts used by the EFL teacher in teaching English in the classroom, there were five types of speech acts employed by the English teacher of grade VII at SMPN 2 Bangli. They were representatives, directives, commissives, expressives and declarations with their percentages of uses respectively $31.91 \%, 47.52 \%, 12.23 \%, 7.62 \%$, and $0.71 \%$.

Among the percentages result from the five types of speech acts above, it showed that directives were the most frequently used speech act by the English teacher during the six meetings of teaching and learning process in the whole grade VII classes with 268 utterances out of 564 utterances $(47.52 \%)$. On the contrary, declaration was the least frequently used speech acts produced by the teacher which occurred only in 4 utterances $(0.71 \%)$.

Dealing with the functions of the speech acts, they appeared in the form of confirming, correcting, agreeing, disagreeing, explaining, informing, stating, predicting, describing, and identifying for representatives, commanding, asking, requesting, suggesting, directing, reminding, warning, prohibiting, and persuading for directives, greeting, thanking, praising, apologizing, wishing, stating surprise, stating pleasure, stating annoyance, stating sorrow, stating anger, stating like, and leave taking for expressives, promising, offering and granting for commissives, naming and declaring for declarations.

Directive was a kind of speech act used by the teacher to get the students to do some actions. Commanding was the most dominant directives function utilized by the teacher which appeared in 119 utterances $(44.40 \%)$. This fact led to the notion that the teacher played her role to manage the classroom instructional system, to counsel the students and their learning, to instruct and to assess. Through directives speech acts, she controlled and managed her classrooms.

From the conclusion elaborated above, some suggestions are proposed to linguistic students, English teachers, and other researchers. It is expected for the linguistic students to learn and explore more about the study of speech acts. By having a well understanding of speech acts, they will be aware of how the language is actually being used. Therefore, any misunderstanding or misconceptions in interpreting the speaker's intended messages will not occur. The English teachers are expected to get an insight in terms of language phenomena dealing with speech acts. It is suggested for them to be able to use English optimally and teach pragmatics to the students so that they know how language should be used. In this case, in order to boost the students' pragmatic awareness and communicative competence, the teachers need to incorporate various learning activities in the classroom. Besides, students' perlocutionary acts toward the teacher's illocutionary forces in the classroom is such an important matter to be considered as an input to improve their pragmatic competence to know how far the classroom communication runs effectively. For other researchers, the results of this study are expected to encourage them to conduct 
similar research by investigating other aspects of pragmatics, such as implicature and politeness. Besides, the students' speech acts can also be worth investigating for the recent study has not been explored yet. In addition, researches on speech acts in more various contexts are strongly recommended.

\section{Reference}

Consolo, D.A. (July/December 2006). Classroom Oral Interaction in Foreign Language Lessons and Implications for Teacher Development. Linguagem \& Ensino, 9(2), 33-55.

Harmanto, B. (2013). Teaching English to Generation Z students (New Concept of Young Learners). Retrieved

from http://eprints.umpo.ac.id/1752/2/6.\%20Teaching\%20Eng\%20Generazion\%20Z.pdf

Hidayat, A. (2016). Speech Acts: Force Behind Words. English Education: Jurnal Tadris Bahasa Inggris. 9(1). 1-12.

Johnson, F, et.al. (1998). Changing Teacher Roles in the Foreign-Language Classroom. Retrieved from https://files.eric.ed.gov/fulltext/ED421013.pdf

Karimnia, A, Afghari, A. (2011). Compliments in English and Persian Interaction: A Cross-Cultural Perspective. Jezikoslovije. 12(1). 27-50.

McCarthy, M. (1991). Discourse Analysis for Language Teachers. Cambridge: Cambridge University Press

Merdana, et.al. (2013). An Analysis of Speech Acts Produced by Elementary School Teachers and Students to Facilitate Teaching and Learning at SDN 10 Pringgasela East Lombok. E-Journal Program Pascasarjana Universitas Pendidikan Ganesha. 1

Miles, M.B and Huberman, A.M. 1994. An Expanded Sourcebook: Qualitative data Analysis, Second Edition. London: Sage Publications.

Nuraini, P.N. (2015). A Pragmatic Analysis of Classroom Speech Acts in The English Teaching and Learning Process at SMA N 1 Purworejo (A Case Study). Unpublished Thesis, Yogyakarta: Yogyakarta State University

Richards, J.C and Schmidt, R. (2002). Longman Dictionary of Language Teaching and Applied Linguistics.Third Edition. Retrieved from http://library.aceondo.net/ebooks/English_Language/dictionary_of_language_teaching_and_applie d_linguistic

Searle, J.R. (April 1976). A Classification of Illocutionary Acts. Language in Society. 5(1). 1-23.

Sriprom, et.al. (January-June 2019). Personality Traits of Thai Gen Z Undergraduates: Challenges in the EFL Classroom? PASAA. 57. 165-190

Spatt, M, et.al. (2009). Cambridge English TKT Teaching Knowledge Test. Retrieved from http://www.cambridgeenglish.org/images/168900-tkt-module-3-part-1-functions-of-teacherlanguage.pdf

Widya, S.O. (2017). A Pragmatic Analysis of Speech Acts Used by English Lecturers in Language Teaching at STKIP YDB Lubuk Alung. Jurnal Arbitrer. 4(1). 10-16.

Yule, G. (1996). Pragmatics. Oxford: Oxford University Press. 